\title{
A comparison between the effects of two cropping methods on the meat quality of impala (Aepyceros melampus)
}

\author{
B. Kritzinger, L.C. Hoffman ${ }^{\#}$ and A.V. Ferreira \\ Department of Animal Sciences, Faculty of Agricultural and Forestry Sciences, University of Stellenbosch, P. Bag X1, \\ Matieland 7602, South Africa
}

\begin{abstract}
Impala (Aepyceros melampus) constitute one of the most commercially important species in game farming in South Africa. The purpose of this study was to compare the effects of day and night cropping on the meat quality characteristics of impala. Emphasis was placed on the influence of the cropping method on muscle $\mathrm{pH}_{45}$ (45 minutes post mortem), $\mathrm{pH}_{\mathrm{u}}$ (ultimate $\left.\mathrm{pH}\right), \mathrm{pH}$ decline, and the related influence on drip loss, cooking loss, toughness and colour of the meat in the M. longissimus lumborum. Measurements taken from 16 animals cropped at night were compared to those taken from 24 animals cropped in daytime. $\mathrm{A}$ mean $\mathrm{pH}_{45}$ of $6.67 \pm 0.11$ was recorded for the night cropped animals compared to a mean $\mathrm{pH}_{45}$ of $6.55 \pm 0.23$ for the day cropped animals. A mean $\mathrm{pH}_{\mathrm{u}}$ of $5.39 \pm 0.08$ for animals cropped at night was recorded compared to a mean $\mathrm{pH}_{\mathrm{u}}$ of $5.45 \pm 0.11$ for the animals cropped in the day. Regression analysis showed the rate of $\mathrm{pH}$ decline to be slower in the night cropped animals compared to those cropped in the day. This persisted when the $\mathrm{pH}$ values were adjusted to correct for ambient temperature. The cooling rate of the M. longissimus lumborum was twice as fast in the night cropped group. Shear force values and drip losses respectively, for the night-cropped animals were $19.11 \pm 5.68 \mathrm{~g} / \mathrm{mm}^{2}$ and $2.93 \pm 1.59 \%$, whereas for the day cropped animals the values were $23.42 \pm 8.13 \mathrm{~g} / \mathrm{mm}^{2}$ and $4.15 \pm 2.34 \%$. The results of this study indicate that night-time cropping does have a beneficial effect on certain meat quality parameters.
\end{abstract}

Keywords: Meat quality, impala, cropping methods

${ }^{\#}$ Corresponding author. E-mail: lch@sun.ac.za

\section{Introduction}

Game ranching is recognised by the South African agriculture and conservation authorities as a bona fide form of agricultural land use (Eloff, 2002). To date there are more than 9000 fenced commercial game farms in the country. A further 15000 farms have game on them that are economically utilised in some form or another (Van Zyl, 2000). The game industry increased by an average of 5.6\% per annum between 1993 and 2000 in terms of the size of exempted game ranches (Eloff, 2002) and excluding Provincial and National Parks, these game farms comprise $12.5 \%$ of South Africa's agricultural land. Van der Waal \& Dekker (2000) calculated that the game ranches in the Limpopo Province alone covered a total surface area of 3.6 million ha in August of 1998, which represents $26 \%$ of the total area of the province. According to these authors, this is part of the generally recognized trend away from conventional livestock production to game production. The reasons for this, when compared to a traditional domestic stock farming operation, are that there is a perceived greater financial return from a game farming operation, it is aesthetically pleasing and ostensibly more environmentally friendly.

The potential of wild ungulates for meat production is something that has been realized for some time now (Ledger, 1963; Ledger et al., 1967; Skinner, 1984). The impala's wide distribution in southern Africa and its relative abundance make it well suited to continuous cropping for game meat production (Bourgarel et al., 2002). In South Africa, the impala is the single most important species in the Lowveld and Bushveld areas in terms of its population numbers (Hoffman, 2000a). A recent study by Eloff (2002) showed that impala are the most popular game species at game auctions, making up almost a third of the total number of animals sold. This is the case because of their relative abundance when compared to other species and the fact that new game farmers who wish to establish game populations on their farms are able to buy them without stretching their financial resources. They tend to be seen as the "bread and butter" of a game farming operation because of their rapid population growth rates (Fairall, 1985) and so they are easily traded. The smaller and newer game farms do not usually have resident predator populations because of restrictive farm sizes and certain financial implications. Without this natural form of population control it soon becomes 
necessary to crop animals in order to prevent overgrazing and destructive interspecies competition. In the light of this growing industry the development of efficient cropping methods for game has become an aspect that requires urgent attention.

Culling methodologies such as the two used in this study are generally accepted practice in South Africa. This is because of the fact that game farming for meat production has not yet reached the same level of sophistication as it has in other parts of the world, like New Zealand and Europe. There, deer farming has become a finely honed industry where partially tame animals are kept in paddocks and slaughtered in commercial abattoirs (Stevenson et al., 1992; Aidoo \& Haworth, 1995; Bradshaw \& Bateson, 2000; Wiklund et al., 2001; Pollard et al., 2002). In South Africa, because of the variability of size and area of the farming terrain, and the long distances between production centres and markets, it is necessary to implement other practical methods to crop game.

Studies on the effects of night shooting on the meat quality of southern African game have been conducted in the past by Hoffman (2000b) and Hoffman \& Ferreira (2000). There has also been some work done on the effects of shooting on the meat quality of wild ungulates by Veary (1991) and Von la Chevallerie \& Van Zyl (1971), but apart from that very little data could be found on the subject. This study was conducted to determine the effects of day- and nighttime cropping on selected meat quality parameters of impala, since there is no such information available. To our knowledge, this is the first study that makes a qualitative comparison between animals harvested at night and those harvested in the day.

\section{Materials and Methods}

The cropping of impala herds took place at the Mara Research Station $\left(23^{\circ} 05^{\prime} \mathrm{S}\right.$ and $29^{\circ} 25^{\prime} \mathrm{E} ; 961$ m.a.s.1.) in the Limpopo Province, South Africa. The study area is located $50 \mathrm{~km}$ west of Makhado (Louis Trichardt), just south of the Soutpansberg mountain range. The Mara Research Station is situated in the Arid Sweet Bushveld (Acocks, 1988) and is 11000 ha in extent. The vegetation found there includes the woody species Acacia tortilis, Commiphora pyracanthoides, Boscia albitrunca and Grewia spp. The grass species found include Eragrostis rigidior, Panicum maximum, Urochloa mosambicensis and Digitaria eriantha. The mean annual rainfall is $452 \mathrm{~mm}$, of which approximately $80 \%$ occurs from November to March. The mean daily maximum temperature ranges from $22.6{ }^{\circ} \mathrm{C}$ in June to $30.4{ }^{\circ} \mathrm{C}$ in January (Dekker et al., 2001). The type of work done there is primarily concerned with research on extensive cattle production. Impala occur naturally in the area and as they are in competition with the cattle for grazing, they are subject to yearly population reductions.

For this study, two cropping methods were used, namely night-time (or spotlight cropping) and daytime. During the night-time (spotlight cropping) operation 16 animals of random age and sex were harvested. Two marksmen (armed with .30 calibre high velocity rifles) and an observer (operating a 1 million-candela spotlight) went out on moonless evenings in a pick-up truck (Lewis et al., 1997). Animals were sighted either directly or by the reflection of light from their retinas. Targeted animals were shot high in the neck so that the bullet destroyed all arterial blood supply to the head as well as the spinal connection to the body. This rendered instantaneous insensibility and resulted in almost no wastage of meat (Von la Chevallerie \& Van Zyl, 1971). Ambient temperatures varied between $2-11^{\circ} \mathrm{C}$.

During the daytime operation, 24 animals of random age and sex were harvested. The animals were hunted on foot and high neck shots were once again used. Each marksman went out alone using the same rifle and ammunition (.30 calibre) as used during the nighttime operation. Ambient temperatures varied between $19-27^{\circ} \mathrm{C}$.

Following the shooting, the dead animals were immediately exsanguinated by cutting the throat with a sharp knife. $\mathrm{pH}\left(\mathrm{pH}_{45}\right)$ and temperature $\left(\mathrm{temp}_{45}\right)$ readings were taken in the $M$. longissimus lumborum using a calibrated (standard buffers at $\mathrm{pH} 4.0$ and $\mathrm{pH}$ 7.0) Crison 506 portable $\mathrm{pH}$ meter (Hoffman, 2000b). The animals were then transported to the abattoir where they were skinned, eviscerated and the carcasses cleaned according to standard South African and Zimbabwean practices (Hoffman, 2000b). The carcasses were then suspended by their Achilles tendons in a cooler set at $4{ }^{\circ} \mathrm{C}$. $\mathrm{pH}$ profiles were taken from five animals selected randomly from those shot in the day and 10 randomly selected animals from those cropped at night, by measuring the $\mathrm{pH}$ and temperature of the carcasses every two hours for the first $12 \mathrm{~h}$, and then every four hours for the following $12 \mathrm{~h}$ post mortem. The $\mathrm{pH}_{\mathrm{u}}$ readings were taken from all of the carcasses $24 \mathrm{~h}$ post mortem. 
Loin samples for proximate and meat quality analyses were taken from the carcasses $36 \mathrm{~h}$ after cropping. The samples were removed from the M. longissimus lumborum between the $1^{\text {st }}$ and $4^{\text {th }}$ lumbar vertebrae. Steaks $(15 \mathrm{~mm}$ in thickness and weighing $c a .70 \mathrm{~g})$ were cut perpendicular to the longitudinal axis of the muscle on the caudal side of the sample. These were used to determine the drip loss and cooking loss according to the methods set out by Honikel (1998). Cooking loss was determined by placing the weighed samples, sealed in polythene bags, into a water bath set at $80^{\circ} \mathrm{C}$ for $1 \mathrm{~h}$. Thereafter the samples were cooled under running water to $25^{\circ} \mathrm{C}$. They were then removed from the bags, blotted dry with paper towelling and weighed. The cooking loss was calculated using the amount of fluid lost during cooking and was expressed as a percentage of the uncooked sample.

For the Warner Bratzler shear force test, five $12.7 \mathrm{~mm}$ diameter samples were cut randomly from the cooked block of meat. Care was taken to ensure that no visible connective tissue was included in the cut section. The samples were cut perpendicular to the longitudinal axis of the muscle fibre so that the influence of the myofibrillar proteins on the shear force could be measured (Voisey, 1976). An average maximum shear force value was calculated (from five repetitions) based on the shear force $\left(\mathrm{g} / \mathrm{mm}^{2}\right)$ required to shear the $12.7 \mathrm{~mm}$ diameter cylindrical core of cooked meat perpendicular to the grain, at a crosshead speed of 228 $\mathrm{mm} / \mathrm{min}$.

For the colour measurement of the meat, freshly cut steaks were allowed to bloom for 20 minutes where-after the colour was measured three times, at random positions on the steak surface (Stevenson et al., 1989) using a Color-guide $45^{\circ} / 0^{\circ}$ colorimeter (BYK-Gardener, USA). The colour was expressed in terms of $\mathrm{L}^{*}, \mathrm{a}^{*}$ and $\mathrm{b}^{*}$ values (Commission International de L' Eclairage, 1976), with L* indicating brightness or reflectance, $\mathrm{a}^{*}$ the red-green range and $\mathrm{b}^{*}$ the blue-yellow range. The hue angles $\left(\mathrm{h}_{\mathrm{ab}}\right)$ and chroma values $\left(\mathrm{C}^{*}\right)$ were calculated for the samples using the following equations (Commission International de $\mathrm{L}^{\text {' }}$ Eclairage, 1976):

$$
\begin{array}{ll}
\text { Hue angle: } & \mathrm{H}_{\mathrm{ab}}=\tan ^{-1}\left(\mathrm{~b}^{*} / \mathrm{a}^{*}\right) \\
\text { Chroma value: } & \mathrm{C}^{*}=\left[\left(\mathrm{a}^{*}\right)^{2}+\left(\mathrm{b}^{*}\right)^{2}\right]^{1 / 2}
\end{array}
$$

Analyses of variance were performed on all the variables measured within treatments using the software package Statistical Analysis System (SAS, 1989). No significant age or sex differences were found so the data were pooled for further analysis. Standard Student t-tests were then conducted with the time of cropping as the main effect. The non-linear regression procedure (Proc NLIN) of SAS (1989) was used to fit exponential decay models to the rate of $\mathrm{pH}$ decline and the rate of temperature decline for both the day and night cropped groups. The model used was in the form of:

$$
y=a+b e^{(-c t)}
$$

where: $\mathrm{y}$ is the dependent variable ( $\mathrm{pH}$ or temperature) and $\mathrm{t}$ is the time (h). The $\mathrm{a}, \mathrm{b}$, and c values from the above mentioned regression model were then analysed using the t-test procedure of SAS (1989) to test for differences between the time of cropping.

As a result of the fact that there were differences found in the rate of muscle temperature decrease between the day and night treatments, the $\mathrm{pH}$ readings were standardized at $4{ }^{\circ} \mathrm{C}$ using the formula of Bruce et al. (2001):

$$
\mathrm{pH}_{\text {adjusted at } \mathrm{t}}=\text { measured } \mathrm{pH}_{\mathrm{t}}+\left\{\left(\mathrm{T}_{\mathrm{t}}-\mathrm{T}_{\text {adjusted }}\right) * 0.01\right\}
$$

where: $\mathrm{pH}_{\mathrm{t}}$ is the actual $\mathrm{pH}$ measured at time $=\mathrm{t}, \mathrm{T}_{\mathrm{t}}$ is the muscle temperature at time $=\mathrm{t}$ and $\mathrm{T}_{\text {adjusted }}$ is the muscle temperature $\left(4{ }^{\circ} \mathrm{C}\right)$ to which the data is being adjusted. The $\mathrm{pH}_{\text {adjusted }}$ was then re-analysed as explained above using Proc NLIN (SAS, 1989).

\section{Results and Discussion}

Night cropping is perceived to be one of the most efficient ways of minimising stress on animals during cropping operations (Lewis et al., 1997). It is of prime importance that cropping operations take place as humanely as possible, so it is necessary to utilise a strategy that best suits the individual circumstances on a particular farm. Tinley (1972) and more recently Veary (1991) reviewed the methods used for cropping and the technique that is most often used, is to shoot at night from a vehicle using spotlights. The impalas' alert and investigative posture that they adopt when caught in the spotlight makes them particularly well suited to night cropping (Lewis et al., 1997). This is in contrast to an animal like the kudu (Tragelaphus strepsiceros) that tends to look away from the spotlight and take flight. 
During the entire cropping operation only one loss occurred: that of an animal that was wounded during the night and never recovered. As a percentage of the total number of animals harvested, this loss makes up less than 2.5\%. According to Lewis et al. (1997) this is well within the expected losses of $\leq 8 \%$ for a cropping operation. All the animals were shot high in the neck and died instantly. There was no wastage of any of the meat owing to the positioning of the shots (Von la Chevallerie \& Van Zyl, 1971). Contrary to a study conducted by Hoffman (2000a), statistical analysis of these data did not show any significant sex differences. The sample sizes used for this study were larger than those sampled by Hoffman (2000a) and the age and sex of animals were randomised.

According to Bruce et al. (2001), the $\mathrm{pH}$ decline of muscle in a carcass deviates from a linear function. This is because when the muscle enters rigor, hydrogen ion production decreases as the rate of anaerobic glycolysis and myosin ATPase activity decrease during muscle cooling. Bendall \& Davey (1957) found that post mortem $\mathrm{pH}$ decline is also slowed by the buffering effect of ammonium generated by the deamination of adenosine monophosphate (AMP). Therefore, because of this slowing in the rate of $\mathrm{pH}$ decline, it is best represented by an exponential decay curve (Bruce et al., 2001).

O'Halloran et al. (1997) noted that the rate of $\mathrm{pH}$ decline influences the toughness of meat particularly if the meat is susceptible to shortening. They went on to show that a slow pH decline increases the shear force value. However, work published by Marsh et al. (1987) showed that a slow rate of post mortem glycolysis produced tender meat. The results of this study are in agreement with the latter. The animals cropped at night showed a slower $\mathrm{pH}$ decline than those shot in the day (Table 1, Figure 1), but their shear force values are significantly lower $(\mathrm{P}<0.05)$ (Table 2). According to the findings of Marsh et al. (1981) moderate rates of $\mathrm{pH}$ decline produce tender loin steaks and they cautioned that rapid $\mathrm{pH}$ decline would produce tough meat.

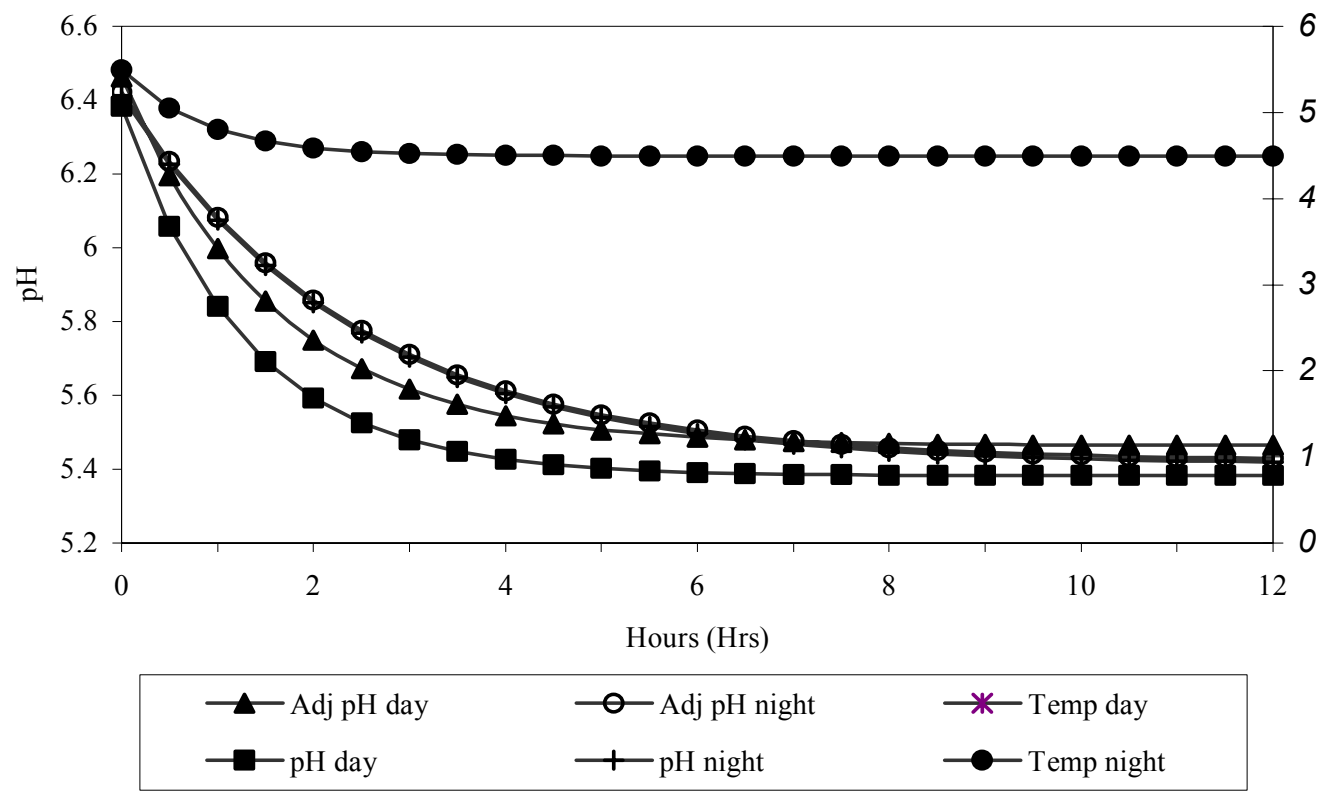

Figure 1 Mean $M$. longissimus lumborum temperature and $\mathrm{pH}$ profiles for day $(\mathrm{n}=5)$ and night $(\mathrm{n}=10)$ cropped impala at Mara

Non-linear regression analysis of the decrease in temperature of impala carcasses suggests that the temperature decrease for both treatments can be accurately described by an exponential decay model (Day: a $=8.03, \mathrm{~b}=31.66, \mathrm{c}=-0.15$; Night: $\mathrm{a}=4.49, \mathrm{~b}=45.33, \mathrm{c}=-0.31)$. The temperature drop of the night cropped group fell twice as fast as that of the day cropped group, thus indicating rapid cooling in the night cropped muscles (Figure 1).

Post mortem muscle that undergoes rapid anaerobic glycolysis usually reaches its ultimate $\mathrm{pH}$ while the temperatures are still high $\left(\approx 20^{\circ} \mathrm{C}\right)$ and might sometimes even show an increase in the apparent muscle $\mathrm{pH}$ as it cools (Bruce et al., 2001). Owing to the differences between the prevailing day and night ambient 
temperatures, it was necessary to adjust the temperatures for both treatments to a standard $4{ }^{\circ} \mathrm{C}$. This was done to remove the variation brought about by the effect of ambient temperature on the $\mathrm{pH}$ declines.

Table 1 The calculated constants (LSMean \pm s.e.) for the exponential equations fitted to the $\mathrm{pH}$ decline under actual temperature conditions and under adjusted standard temperature $\left(4^{\circ} \mathrm{C}\right)$ for day $(\mathrm{n}=5)$ and night $(\mathrm{n}=10)$ cropped impala

\begin{tabular}{cccccc}
\hline $\begin{array}{c}\mathrm{y}=\mathrm{a}+\mathrm{b} e^{-\mathrm{ct}} \\
\text { constants }\end{array}$ & $\mathrm{T}$ & Normal $\mathrm{pH}$ decline & $\mathrm{P}<|\mathrm{t}|$ & $\begin{array}{c}\mathrm{pH} \text { decline adjusted to std } \\
\text { temp }\end{array}$ & $\mathrm{P}<|\mathrm{t}|$ \\
\hline $\mathbf{a}$ & $\mathrm{D}$ & $5.38 \pm 0.006$ & $<0.01$ & $5.46 \pm 0.006$ & $<0.01$ \\
& $\mathrm{~N}$ & $5.41 \pm 0.004$ & & $5.42 \pm 0.004$ & \\
& $\mathrm{D}$ & $2.93 \pm 0.124$ & $<0.01$ & $2.90 \pm 0.086$ & $<0.01$ \\
& $\mathrm{~N}$ & $2.14 \pm 0.083$ & & $2.47 \pm 0.057$ & $<0.01$ \\
& $\mathrm{D}$ & $-0.72 \pm 0.040$ & $<0.01$ & $-0.58 \pm 0.027$ & $-0.45 \pm 0.018$ \\
\hline
\end{tabular}

$\mathrm{T}($ Time $)=\mathrm{D}$ (Day) or N (Night)

The $\mathrm{pH}$ decline under the prevailing ambient temperatures in the day and night differed significantly, with the day cropped group having a more rapid rate of $\mathrm{pH}$ decline. The analysis was repeated after the temperature was adjusted to a standard $4{ }^{\circ} \mathrm{C}$ for both treatments (Figure 1, Table 1). The difference in $\mathrm{pH}$ between day and night cropping persisted with the standardised temperature and is likely as a result of the difference in ante mortem conditions experienced by the animals prior to death between the day and night treatments. It is likely that the difference arose as a result of the heightened stress level of the day cropped animals because of their awareness of the hunters. Another influence could be the heightened level of physical activity during the day, particularly during the rut, which would cause the glycolytic enzyme activity to remain high for a longer period, resulting in a more rapid $\mathrm{pH}$ decline. The relative unawareness of the animals of the croppers (and thus unstressed state) during night cropping would result in a lowered glycolytic enzyme activity and a slower rate of $\mathrm{pH}$ decline.

The $\mathrm{pH}_{45}$ of the animals cropped at night was significantly higher than those shot in the day $(\mathrm{P}<$ 0.05; Table 2). However, the $\mathrm{pH}_{\mathrm{u}}$ of the day cropped animals was higher than those of the group harvested at night $(\mathrm{P}<0.05)$. The fact that the day-cropped $\mathrm{pH}_{45}(6.55 \pm 0.24)$ was lower than those of the night cropped animals $(6.67 \pm 0.11)$ may be attributed to the daytime activities of the animals. The study took place during May and June, and coincided with the impala rutting, or mating period (Fairall, 1985). This period is characterised by heightened physical activity for both sexes associated with mating behaviour (such as fighting, mounting, oestrus and gestation) and such activity necessitates the mobilisation of additional muscle glycogen (both aerobically and anaerobically, depending on the intensity of the activity).

Table 2 Mean $\mathrm{pH}$ values and physical meat quality parameters (LSMean \pm s.e.) for the day $(\mathrm{n}=24)$ and night $(\mathrm{n}=16)$ cropped impala at Mara

\begin{tabular}{lccc}
\hline & Day cropped & Night cropped & $\mathrm{P}<|\mathrm{t}|$ \\
\hline $\mathrm{Mean} \mathrm{pH}_{45}$ & $6.55 \pm 0.235$ & $6.67 \pm 0.111$ & 0.05 \\
$\mathrm{Mean} \mathrm{pH}_{\mathrm{u}}$ & $5.45 \pm 0.108$ & $5.39 \pm 0.081$ & 0.05 \\
Drip loss (\%) & $4.15 \pm 2.339$ & $2.93 \pm 1.597$ & 0.05 \\
Cooking loss $(\%)$ & $32.87 \pm 4.101$ & $32.99 \pm 5.109$ & 0.90 \\
Warner Bratzler shear force $\left(\mathrm{g} / \mathrm{mm}^{2}\right)$ & $23.42 \pm 8.128$ & $19.11 \pm 5.675$ & 0.05 \\
\hline
\end{tabular}

A second aspect that would most certainly constitute a stress factor to the day-cropped animals is their awareness of the hunter. Lacourt \& Tarrant (1985) mimicked the effect of this type of stress by administering exogenous doses of adrenaline to young bulls. Among the physiological responses that they reported, was a decline in the muscle glycogen content of such animals. This is in keeping with similar findings by Pollard et al. (2002) for red deer (Cervus elaphus). Muscle glycogen is the main metabolic substrate that is responsible for the formation of lactic acid, and thus normal post mortem $\mathrm{pH}$ decline of 
muscle (Immonen et al., 2000). The depletion of glycogen by one or other chronic form of stress before death will result in less lactic acid being formed and consequently the meat will not acidify properly and the $\mathrm{pH}_{\mathrm{u}}$ will remain high (Viljoen et al., 2002). The relationship between elevated $\mathrm{pH}_{\mathrm{u}}$ and physical activity or chronic stress in deer has been observed in several studies (MacDougall et al., 1979; Kay et al., 1981; Smith \& Dobson, 1990). Knox et al. (1991) found that the stress and exertion associated with the live capture of impala significantly raised the plasma lactate concentrations in the blood and muscles. They attributed this to the heightened muscular activity during the capture, which resulted in anaerobic glycolysis and the subsequent accumulation of lactic acid in the muscle tissue and blood. Hattingh et al. (1988) have reported similar findings. Increases in lactic acid concentrations in the tissue have been reported by Gericke et al. (1978) for springbok (Antidorcas marsupialis), Hofmeyer et al. (1973) for zebra (Equus burchelli) and by Harthoorn (1975) for eland (Taurotragus oryx) and tsessebe (Damaliscus lunatus). Ruminant animals usually have a lower blood glucose concentration than non-ruminant animals (Schaefer et al., 1997) and this contributes to a lower muscle glycogen content as well as a slower rate of glycogen repletion. However, at night, glycogen stores are replenished causing the muscle $\mathrm{pH}_{45}$ to be slightly higher (McVeigh \& Tarrant, 1982). It is therefore probable that the $\mathrm{pH}_{\mathrm{u}}$ of the night-cropped animals is lower because of the greater amount of muscle glycogen available for post mortem glycolysis. The amount of muscle glycogen available for post mortem glycolysis, together with the temperature regime, also affects the rate of $\mathrm{pH}$ decline.

An important aspect of meat quality that ties in with the ultimate $\mathrm{pH}$ is the water binding capacity of the meat. The point of minimum water binding capacity is the iso-electric point, which is $\mathrm{pH} 5.4-5.5$. Post mortem glycolysis usually reduces the ultimate $\mathrm{pH}$ of meat to around $5.4-5.5$, so some moisture loss due to loss of water binding capacity is inevitable. A large proportion of the water present in muscle is found in the myofibrils between the actin and myosin filaments (Lawrie, 1998). Roughly 5\% of it is bound to the hydrophilic groups on these proteins (Hamm, 1966). The higher the ultimate $\mathrm{pH}$, the less water will be released by the tissue. Offer \& Knight (1988) showed that drip loss is formed primarily from the extracellular space and that the latter increases with decreasing $\mathrm{pH}$. Guignot et al. (1993) confirmed this in veal muscle. The night-cropped animals had a higher mean $\mathrm{pH}_{\mathrm{u}}$ and lower average drip-loss compared to the day-cropped animals $(\mathrm{P}<0.05$; Table 2). Numerous other reports have noted the association between decreased water holding capacity and increased $\mathrm{pH}_{\mathrm{u}}$ (Dransfield et al., 1981; Purchas, 1990). The higher $\mathrm{pH}_{\mathrm{u}}$ of the daycropped animals is conducive to lowered water binding capacity and therefore a greater percentage of driploss. In a study conducted by Hoffman (2000b), drip loss values of $2.61 \pm 1.24 \%$ and cooking loss values of $23.98 \pm 1.41 \%$ were reported for impala cropped at night in central Zimbabwe. The drip loss reported by this author is very similar to the drip loss for the night cropped group of the present study.

The amount of cooking loss did not differ significantly between the day and night cropped groups (Table 2). The Warner-Bratzler shear force tests showed that the meat from the night cropped group was significantly more tender than that of the day cropped group $(\mathrm{P}<0.05)$. Devine et al. (1993) found the same trend towards decreasing tenderness with increasing $\mathrm{pH}_{\mathrm{u}}$ in lambs. A higher $\mathrm{pH}_{\mathrm{u}}$ can lead to the association of the actin and myosin filaments of the day-cropped animals leading to shortening and decreased tenderness (Ouali, 1990).

The colour of meat is of critical importance in creating an impression when meat is viewed (Clydesdale, 1991; Gasperlin et al., 2000) and is used as an indicator of flavour, tenderness and freshness (Naumann et al., 1957). No significant differences between the two treatments were noted in so far as the colour of the meat was concerned (Table 3$)$. The hue angle $\left(\mathrm{h}_{\mathrm{ab}}\right)$ and chroma $\left(\mathrm{C}^{*}\right)$ values were also calculated for the samples using the $a^{*}$ and $b^{*}$ values, but they did not show any significant difference between the groups. Hoffman $(2000 \mathrm{~b})$ recorded similar colorimetric values of $* \mathrm{~L}=29.22, * \mathrm{a}=11.26$ and $* \mathrm{~b}=7.76$ for impala that were also cropped at night.

It is well known that game meat is darker in colour than other meat. The darker colour of game meat may be ascribed to the elevated levels of myoglobin present in the muscle (Vestergaard et al., 2000; Diaz et al., 2002). This elevated myoglobin content and thus darker meat colour is possibly due to the fact that wild ungulates are much more active than domesticated animals such as cattle and sheep. Studies have shown that there is an increase in myoglobin concentrations in muscle as a result of systematic exercise (Lawrie, 1998; Vestergaard et al., 2000; Diaz et al., 2002). However, the darker colour of the meat may also, in part, be as a result of the relatively less intra-muscular fat present (Janicki et al., 1963), since it has been found that the impala has less intra-muscular fat than domestic livestock (Hoffman, 2000a). When carcasses have a higher $(\geq 5.7) \mathrm{pH}_{\mathrm{u}}$, light transmittance through the fibres is high and the diffusion of that light is small, so meat 
colour appears darker (Swatland, 1990). It is likely that the darker colour of game meat makes it difficult to measure possible subtle differences in the colour that may have arisen as a result of marginally stressful conditions.

Consumer perception of game meat in South Africa is often unfavourable because of its dark colour (Von la Chevallerie, 1972). This has a negative effect on its popularity because many consumers prefer meat that is neither dark nor pale (Jeremiah et al., 1972). Dark, firm and dry (DFD) meat is a common occurrence with game meat because of the often highly stressful conditions in which game is harvested. Hoffman (2000b) recorded values of $L^{*}=25.44, a^{*}=9.13$ and $b^{*}=4.88$ for a male animal that was wounded and subsequently subjected to severe ante mortem stress for a period of 10 minutes. The animal had the darkest meat and the fastest $\mathrm{pH}$ decline and was said to have the DFD condition. All of the animals cropped in this study were in a calm state directly prior to cropping. So it is unlikely that any of them experienced the type of circumstances conducive to the DFD condition. Their relatively higher colorimetric values (Table 3) than those reported for the stressed animal by Hoffman (2000a) are evidence of this.

Table 3 Colorimetric values (LSMean \pm s.e.) for the day $(n=24)$ and night $(n=16)$ cropped impala

\begin{tabular}{cccc}
\hline & Day cropped & Night cropped & $\mathrm{P}>|\mathrm{t}|$ \\
\hline $\mathrm{L}^{*}$ & $30.53 \pm 2.758$ & $30.10 \pm 1.296$ & 0.50 \\
$\mathrm{~A}^{*}$ & $12.52 \pm 1.361$ & $13.19 \pm 1.475$ & 0.15 \\
$\mathrm{~b}^{*}$ & $8.75 \pm 1.422$ & $9.42 \pm 1.780$ & 0.20 \\
$\mathrm{C}^{*}$ & $15.85 \pm 2.159$ & $15.99 \pm 1.856$ & 0.80 \\
$\mathrm{~h}_{\mathrm{ab}}$ & $0.59 \pm 0.084$ & $0.62 \pm 0.058$ & 0.20 \\
\hline
\end{tabular}

\section{Conclusions}

The results of the $\mathrm{pH}$ data, drip loss and shear force analyses clearly show that night cropping yields a better meat quality than day cropping. The slower rate of $\mathrm{pH}$ decline of the night cropped group shows that conditions during night cropping are more favourable for meat quality than day cropping. Night cropping does not seem to have any detrimental effects on meat quality and it can be deduced that this is as a result of lower ante mortem stress to the animals.

Owing to the very low night-time ambient temperatures, it is possible that animals cropped at night could develop cold shortening. However, this specific aspect requires further research.

\section{Acknowledgements}

This study was made possible by a grant from the Technology and Human Resource for Industry Programme. The authors would like to thank the Limpopo Province Department of Agriculture, Land and Environment for the use of their facilities at the Mara Agricultural Development Centre. The authors wish to thank the following people and their families for their assistance with the study: B. Dekker, I. du Plessis, and C. van der Waal.

\section{References}

Acocks, J.P.H., 1988. Veld types of South Africa. Memoirs of the Botanical Survey of South Africa. 57 p. Aidoo, K.E. \& Haworth, R.J.P., 1995. Nutritional and chemical composition of farmed venison. J. Hum. Nutr. Diet. 8, 441-446.

Bendall, J.R. \& Davey, C.L., 1957. Ammonia liberation during rigor mortis and its relation to changes in the adenine and inosine nucleotides of rabbit muscle. Biochim. et Biophys. Acta 26, 93-103.

Bourgarel, M., des Clers, B., Roques-Rogery, D., Matabilila, J. \& Banda, M., 2002. The sustainable use of game: Production of cheap edible meat for local communities in a Zimbabwean communal area. In: Sustainable Utilisation - Conservation in Practice. Eds Ebedes, H., Reilly, B., Van Hoven, W. \& Penzhorn, B., Proc. $5^{\text {th }}$ Int. Wildlife Symp. pp. 199-206.

Bradshaw, E.L. \& Bateson, P., 2000. Welfare implications of culling red deer (Cervus elaphus). Anim. Welf. 9, 3-24.

Bruce, H.L., Scott, J.R. \& Thompson, J.M., 2001. Application of an exponential model to early post mortem bovine muscle $\mathrm{pH}$ decline. Meat Sci. 58, 39-44.

Clydesdale, F.M., 1991. Color perception and food quality. J. Food Qual. 14, 61-68. 
Commission International de L' Eclairage., 1976. Colorimetry, $2^{\text {nd }}$ Ed. CIE, Vienna.

Dekker, B., Kirkman, K.P. \& Du Plessis, S.I., 2001. Use of the dry-weight-rank method of botanical analysis in semi-arid savanna communities. Afr. J. Range. For. Sci. 63, 124-128.

Devine, C.E., Graafhuis, A.E., Muir, P.D. \& Chrystall, B.B., 1993. The effect of growth rate and ultimate pH on meat quality of lambs. Meat Sci. 35, 63-77.

Diaz, M.T., Velasco, S., Caňeque, V., Lauzurica, F., Ruiz de Huidobro, F., Pérez, C., González, J. \& Manzanares, C., 2002. Use of concentrate or pasture for fattening lambs and its effect on carcass and meat quality. Meat Sci. 43, 257-268.

Dransfield, E., Jones, R.C.D. \& MacFie, H.J.H., 1981. Tenderising in M. longissimus dorsi of beef, veal, rabbit, lamb and pork. Meat Sci. 5, 139-147.

Eloff, T., 2002. The economic realities of the game industry in South Africa. In: Sustainable Utilisation Conservation in Practice. Eds. Ebedes, H., Reilly, B., Van Hoven, W. \& Penzhorn, B., Proc. $5^{\text {th }}$ Int. Wildlife Symp. pp 78-86.

Fairall, N.,1985. Manipulation of age and sex ratios to optimize production from impala Aepyceros melampus populations. S. Afr. J. Wildl. Res. 15(3), 85-88.

Gasperlin, L., Zlender, B. \& Abram V., 2000. Colour of normal and high pH beef heated to different temperatures as related to oxygenation. Meat Sci. 54, 391-398.

Gericke, M.D., Hofmeyer, J.M. \& Louw, G.N., 1978. The effect of capture stress and haloperidol therapy on the physiology and blood chemistry of springbok, Antidorcas marsupialis. Madoqua 11, 5-18.

Guignot, F., Vignon, X. \& Monin, G., 1993. Post mortem evolution of myofilament spacing and extracellular space in veal muscle. Meat Sci. 33, 333-347.

Hamm, R., 1966. Die verarbeitung von schlachtwarm eingefrorenem fleisch. Fleischwirtschaft 18, 856- 859.

Harthoorn, A.M., 1975. The physiology and therapy of capture myopathy. Part 3. $4^{\text {th }}$ Annual report to the Transvaal Nature Conservation Division, Pretoria, South Africa.

Hattingh, J., Pitts, N.I. \& Ganhao, M.F., 1988. Immediate response to repeated capture and handling of wild impala. J. Exper. Zool. 248, 109-112.

Hoffman, L.C., 2000a. The yield and carcass chemical composition of impala (Aepyceros melampus), a southern African antelope species. J. Sci. Food Agric. 80, 752-756.

Hoffman, L.C., 2000b. Meat quality attributes of night cropped impala (Aepyceros melampus). S. Afr. J. Anim. Sci. 30, 133-137.

Hoffman, L.C. \& Ferreira, A.V., 2000. pH decline of the M. longissimus thoracis of night cropped grey duiker (Sylvicapra grimmia). S. Afr. J. Anim. Sci. 30, 16-17.

Hofmeyer, J.M., Louw, G.N. \& Du Preez, J.S. 1973. Incipient capture miopathy as revealed by blood chemistry of chased zebras. Madoqua 1, 45-50.

Honikel, K.O., 1998. Reference methods for the assessment of physical characteristics of meat. Meat Sci. 49, 447-457.

Immonen, K., Ruusunen, M. \& Puolanne, E., 2000. Some effects of residual glycogen concentration on the physical sensory quality of normal $\mathrm{pH}$ beef. Meat Sci. 55, 33-38.

Janicki, M.A., Kolaczyk, S. \& Kortz, J., 1963. Factors that affect consumer perceptions of meat. Proc. $9^{\text {th }}$ Meeting of Meat Research Workers, Budapest.

Jeremiah, L.E., Carpenter, Z.L. \& Smith, G.C., 1972. Beef color as related to consumer acceptance and palatability. J. Food Sci. 37, 476-479.

Kay, R.N.B., Sharman, G.A.M., Hamilton, W.J., Goodall, E.D., Pennie, K. \& Coutts, A.G.P., 1981. Carcass characteristics of young red deer farmed in hill pasture. J. Agric. Sci., Camb. 96, 79-87.

Knox, C.M., Hattingh, J. \& Raath, J.P., 1991. The effect of zeranol on body mass and physiological responses to repeated capture in boma-confined impala. S. Afr. J. Wildl. Res. 21(2), 38-42.

Lacourt, A. \& Tarrant, P.V., 1985. Glycogen depletion patterns in myofibres of cattle during stress. Meat Sci., 15, 85-89.

Lawrie, R. A., 1998. Lawrie's Meat Science. $6^{\text {th }}$ ed. Woodhead Publ. Ltd Cambridge, England.

Ledger, H.P., 1963. Animal husbandry research and wildlife in East Africa. E. Afr. Wildl. J. 1, 18-22.

Ledger, H.P., Sachs, R. \& Smith, N.S., 1967. Wildlife and food production. Wrld Rev. Anim. Prod. 3, 13-16.

Lewis, A.R., Pinchin, A.M. \& Kestin, S.C., 1997. Welfare implications of the night shooting of wild impala (Aepyceros melampus). Anim. Welf. 6, 123-131.

MacDougall, D.B., Shaw, B.G., Nute, G.R. \& Rhodes, D.N., 1979. Effect of pre-slaughter handling on the quality and microbiology of venison from farmed young red deer. J. Sci. Food Agric. 30, 1160-1167. 
Marsh, B.B., Lochner, J.V., Takahashi, G. \& Kragness, D.D., 1981. Effects of early post-mortem pH and temperature on beef tenderness. Meat Sci. 5, 479-483.

Marsh, B.B., Ringkob, T.P., Russel, R.L., Swartz, D.R. \& Pagel, L.A., 1987. Effects of early-postmortem glycolytic rate on beef tenderness. Meat Sci. 21, 241-248.

McVeigh, J.M. \& Tarrant, P.V., 1982. Glycogen content and repletion in beef muscle, effect of feeding and fasting. J. Nutr. 112, 1306-1307.

Naumann, H.D., Rhodes, V.J., Brady, D.E. \& Kiehl, E.R., 1957. Discrimination techniques in meat acceptance studies. Food Tech. 2, 123-128.

Offer, G. \& Knight, P., 1988. In: Developments in Meat Science - 4. Ed. Lawrie, R., Elsevier Science Publishers Ltd, London \& New York. pp. 63-243.

O'Halloran, G.R., Troy, D.J. \& Buckley, D.J., 1997. The relationship between early post mortem pH and the tenderisation of beef muscles. Meat Sci. 45, 239-251.

Ouali, A., 1990. Meat tenderisation: possible causes and mechanisms. A review. J. Muscle Foods 1, 129-132.

Pollard, J.C., Littlejohn, R.P., Asher, G.W., Pearse, A.J.T., Stevenson-Barry, J.M., McGregor, S.K., Manley, T.R., Duncan, S.J., Sutton, C.M., Pollock, K.L. \& Prescott, J., 2002. A comparison of biochemical and meat quality variables in red deer (Cervus elaphus) following either slaughter at pasture or killing at a deer slaughter plant. Meat Sci. 60, 85-94.

Purchas, R.W., 1990. An assessment of the role of $\mathrm{pH}$ differences in determining the relative tenderness of meat from bulls and steers. Meat Sci. 27, 129-140.

SAS, 1989. Statistical Analysis Systems users' guide. (The SAS System for Windows, Version 8.2), SAS Institute Inc., Cary, North Carolina, USA. 1028 p.

Schaefer, A.L., Jones, S.D.M. \& Stanley R.W., 1997. The use of electrolyte solutions for reducing transport stress. J. Anim. Sci. 75, 258-265.

Skinner, J.D., 1984. Selected species of ungulates for game farming in Southern Africa. Acta Zool. Fenn. $172,219-223$.

Smith, R.F. \& Dobson, H., 1990. The effect of pre-slaughter handling experience on behaviour, plasma cortisol and muscle $\mathrm{pH}$ in farmed red deer. Vet. Rec. 126, 155-158.

Stevenson, J.M., Seman, D.L. \& Littlejohn, R.P., 1992. Seasonal variation in venison quality of mature, farmed red deer stags in New Zealand. J. Anim. Sci. 70, 1389-1396.

Stevenson, J.M., Seman, D,L., Weatherall, I.L. \& Littlejohn, R.P., 1989. Evaluation of venison color by an objective method using Cielab values. J. Food Sci. 54, 1661-1662.

Swatland, H.J., 1994. Physical measurements of meat quality: optical measurements, pros and cons. Meat Sci. 36, 251-259.

Tinley, M., 1972. Cropping techniques. In: Ungulate management. Ed. Mentis, M.T., Natal Parks Game and Fish Preservation Board, Natal, South Africa.

Van der Waal, C. \& Dekker B., 2000. Game ranching in the Northern Province of South Africa. S. Afr. J. Wildl. Res. 30, 151-156.

Van Zyl, J., 2000. Wildplase verg slimmer planne. Finansies \& Tegniek. October. pp. 32-37.

Veary, C.M., 1991. The effect of three slaughter methods and ambient temperature on the $\mathrm{pH}$ and temperatures in springbok (Antidorcas marsupialis) meat. Mmed Vet (hyg) thesis. Faculty of Veterinary Science, University of Pretoria, South Africa.

Vestergaard, M., Oksbjerg, N. \& Henckel, P., 2000. Influence of feeding intensity, grazing and finishing feeding on muscle fibre characteristics and meat colour of semitendinosus, longissimus dorsi and supraspinatus muscles in young bulls. Meat Sci. 54, 177-185.

Viljoen, H.F., De Kock, H.L. \& Webb E.C., 2002. Consumer acceptability of dark, firm and dry (DFD) and normal $\mathrm{pH}$ beef steaks. Meat Sci. 61, 181-185.

Voisey, P.W., 1976. Engineering assessment and critique of instruments used for meat tenderness evaluation. J. Text. Stud. 7, 11-13.

Von la Chevallerie, M., 1972. Meat quality aspects of seven wild ungulate species. S. Afr. J. Anim. Sci. 1, 113-116.

Von la Chevallerie, M. \& Van Zyl, J.H.M., 1971. Some effects of shooting losses of meat and meat quality in springbok and impala. S. Afr. J. Anim. Sci. 1, 113-116.

Wiklund, E., Stevenson-Barry, J.M., Duncan, S.J. \& Littlejohn, R.P., 2001. Electrical stimulation of red deer (Cervus elaphus) carcasses - effects on rate of $\mathrm{pH}$-decline, meat tenderness, colour stability and water-holding capacity. Meat Sci. 59, 211-220. 